DOI: https://doi.org/10.24127/ajpm.v10i2.3571

\title{
THE IMPLEMENTATION OF BLENDED LEARNING-BASED MODEL E-LEARNING MOODLE
}

\author{
Dona Fitriawan $^{1 *}$, Wardah $^{2}$ \\ 1* Mathematics Education, Universitas Tanjungpura Pontianak, Indonesia \\ ${ }^{2}$ English Education, IAIN Pontianak, Indonesia \\ *Corresponding author. \\ E-mail: $\quad$ donafitriawan@fkip.untan.ac.id ${ }^{\left.{ }^{*}\right)}$ \\ $\underline{\text { wardah@iainptk.ac.id }}^{2)}$
}

Received 17 February 2021; Received in revised form 22 June 2021; Accepted 01 July 2021

\begin{abstract}
The objectives of this study are: 1) Implementing blended learning model based on e-learning Moodle into learning; 2) whether the blended learning model based on Moodle e-learning can improve learning achievement. The type of research in this research is descriptive-explorative qualitative, which explores all the things that are in the processing of questions and answers to students' steps and explores the results of the interview survey with students. The subjects in this study were 21 class B students. The research instruments were tests, surveys, questionnaires, and interviews. The results of research and discussion show the implementation of the lecture process, face to face with zoom metting, presence in applications, assignments, and testing. From the results of the research and discussion, it is concluded that: 1) the blended learning model based on e-learning Moodle has been successfully implemented into linear learning program courses, 2) From the results of tests, questionnaires, surveys and interviews with ebased blended learning model students -learning moodle has increased their achievement and enthusiasm for learning
\end{abstract}

Keywords: Blended learning; e-learning moodle; implementation.

\begin{abstract}
Abstrak
Tujuan dari penelitian ini adalah: 1) Mengimplementasikan model blended learning berbasis e-learning moodle ke dalam pembelajaran; 2) apakah model blended learning berbasis e-learning moodle dapat meningkatkan prestasi belajar. Jenis penelitian dalam penelitian ini adalah kualitatif deskriptif-eksploratif yakni mengeksplorasi semua hal yang ada dalam pengerjaan soal dan langkah-langkah jawaban peserta didik serta mengekplorasi hasil survey wawancara dengan mahasiswa. Subjek dalam penelitian ini adalah 21 mahasiswa kelas B. Instrument penelitiannya berupa tes, survey, angket, dan wawancara. Hasil penelitian dan pembahasan menunjukkan implementasi proses perkuliahan, tatap muka dengan zoom meeting, presensi di aplikasi, pemberian tugas, dan pengujian. Dari hasil penelitian dan pembahasan diperoleh kesimpulan bahwa: 1) model blended learning berbasis e-learning moodle telah berhasil diimplementasikan ke dalam pembelajaran mata kuliah program linier dengan baik, 2) Dari hasil tes, angket, survey dan wawancara kepada mahasiswa model blended learning berbasis e-learning moodle telah meningkatkan prestasi dan semangat belajar mereka.
\end{abstract}

Kata kunci: Blended learning; e-learning moodle; implementasi.

This is an open access article under the Creative Commons Attribution 4.0 International License

\section{INTRODUCTION}

The essence of learning is a process of communication in the form of oral communication between students and educators as well as between fellow students in the context of changing attitudes and behavior. (Jihad \& Haris, 2013); (Sari, 2019). Through the learning process, they together become actors in the implementation of 
effective learning objectives, namely learning that makes it easier for students to learn something useful such as facts, skills, values, concepts, and how to live in harmony with others, or a desired learning outcome.

The blended learning model combines two types of learning, namely e-learning or online learning and faceto-face learning. Online learning is meant by utilizing the internet network which consists of website-based learning which is also known as learning in the network. This blended learning is a combination of multimedia-based technology development, CD ROM, streaming video, email, voice mail and others by combining face-to-face learning in class. Face-to-face learning gives students the opportunity to ask questions or problems related to the material taught by the teacher. This online learning or also called distance learning, where teachers / lecturers and students can do learning outside of school / campus even though educators and students are not in one room or not face to face. Lecturers give tutorials or teachers give assignments to students which sources of subject matter can be accessed on the internet. (Musa dalam (Abdullah, 2018); (Idris, 2018)).

The blended learning model combines face-to-face learning with the help of Information and Communication Technology (ICT) with advantages, namely: 1) students interact directly with the content of learning, 2) can interact with friends, 3) discuss groups and exchanging opinions, 4) accessing e-libraries, virtual classes, 5) online assessments, 6) e-tuitions, 7) accessing and maintaining learning blogs, 8) online seminars (webinars), 9) seeing expert lecturers on YouTube, 10) online learning via video and audio, 11) virtural laboratory. (Manggabarani et al., 2016); (Wardani et al., 2018); (Rachman et al., 2019).

The composition of blended learning that is often used is the 50/50 pattern, in the time allocation available $50 \%$ face-to-face $50 \%$ online learning, some also use the $75 / 25$ pattern, meaning $75 \%$ face-to-face meetings $25 \%$ online learning, and there are also those who apply $25 / 75,25 \%$ use faceto-face learning $75 \%$ use online learning. In using this pattern, it depends on the competency analysis required, subject objectives, learner characteristics, learner characteristics and abilities and available resources. However, the main consideration in designing the composition of learning is the provision of suitable learning resources for various characteristics of learners so that learning becomes attractive, effective and efficient. In this study, a composition of $25 \%$ face to face and $75 \%$ online was used. (Amin, 2017); (Hidayat et al., 2020).

Moodle LMS is software that functions to provide facilities and an Internet-based learning environment. With a web interface, Moodle has features that are complete enough to present courses where teachers can upload learning materials. In this case, the application made uses the cloud computing model. Cloud computing is a model that allows ubiquitous computing to be done on-demand by accessing the network to compute resources, such as storage. Students can $\log$ in to the Moodle system, then choose the course provided or do enrollment. With this application, the activities of students in Moodle can be continuously monitored. (Rizal \& Walidain, 2019); (Azis, 2015).

In connection with the need for innovation, it is necessary to develop an alternative learning, namely Moodle e- 
learning with the objectives of the research are: 1) implementing Moodle e-learning based blended learning model into learning; 2) whether the blended learning model based on Moodle e-learning can improve learning achievement; 3) the magnitude of the increase in learning achievement with the blended learning model based on elearning moodle.

\section{METHODS}

The type of research in this research is descriptive-explorative qualitative, which explores all the things that are in the processing of the questions and the steps for the answers of students and explores the results of the interview survey with students.

The research stages started from the application of blended learning based on e-learning moodle, then written test activities, class surveys, distributing questionnaires, and giving response sheets to students. Written tests are used to see how their learning outcomes are, class surveys to survey teaching and learning activities during learning, questionnaires are distributed to see how enthusiastic they are in learning, and response sheets are used to see the extent to which students' positive responses use this e-learning moodle-based blended learning model.

The subjects in this study were 21 students of the B class linear program of the Mathematics Education Study Program, FKIP Tanjungpura University. Data collection techniques with tests, surveys, observations, and responses. Test data is used to obtain written learning outcomes tests, surveys to survey ongoing learning, written questionnaires to see students' enthusiasm for learning, and responses to see how successful the implementation of this learning model.
The research instruments were written tests, survey tests, questionnaire sheets, and student response tests.

The data analysis technique was analyzed by descriptive-explorative statistics. According to (Sugiyono, 2017), descriptive-exploratory statistics is exploring all the data that has been collected by describing or describing the data used as they are without intending to make general conclusions or generalizations. Data from the results of written tests, surveys, questionnaires, and responses were then explored descriptively to get conclusions according to the problem formulation.

\section{RESULTS AND DISCUSSION}

To find out student learning outcomes, a test of learning outcomes was carried out. The result of the test can be seen in Table 1 .

Table 1. Student exam results

\begin{tabular}{ccc}
\hline No & Name & Score \\
\hline 1 & $\mathrm{Af}$ & 80,50 \\
2 & $\mathrm{Ag}$ & 75,38 \\
3 & $\mathrm{Ai}$ & 71,50 \\
4 & $\mathrm{Am}$ & 75,00 \\
5 & $\mathrm{An}$ & 75,00 \\
6 & $\mathrm{As}$ & 75,50 \\
7 & $\mathrm{Az}$ & 80,88 \\
8 & $\mathrm{Ca}$ & 72,00 \\
9 & $\mathrm{Jf}$ & 75,50 \\
10 & $\mathrm{Ks}$ & 73,50 \\
11 & $\mathrm{Kt}$ & 73,50 \\
12 & $\mathrm{Md}$ & 74,75 \\
13 & $\mathrm{~N}$ & 75,00 \\
14 & $\mathrm{Na}$ & 80,88 \\
15 & $\mathrm{Ni}$ & 75,50 \\
16 & $\mathrm{Nu}$ & 75,00 \\
17 & $\mathrm{Rp}$ & 74,38 \\
18 & $\mathrm{Vi}$ & 80,50 \\
19 & $\mathrm{Vn}$ & 75,50 \\
20 & $\mathrm{Wh}$ & 82,88 \\
21 & $\mathrm{Wi}$ & 73,50 \\
\hline
\end{tabular}

Sumber: siakad.untan.ac.id 
DOI: https://doi.org/10.24127/ajpm.v10i2.3571

From the data in Table 1, then processed with SPSS 24. The result of statistical test can be seen in Table 2.

Table 2. Statistical test results

\begin{tabular}{ccccc}
\hline & $\begin{array}{c}\mathrm{N} \\
\text { Statistic }\end{array}$ & $\begin{array}{c}\text { Range } \\
\text { Statistic }\end{array}$ & $\begin{array}{c}\text { Minimum } \\
\text { Statistic }\end{array}$ & $\begin{array}{c}\text { Maksimum } \\
\text { Statistic }\end{array}$ \\
\hline Score & 21 & 11,38 & 71,50 & 82,88 \\
Valid N & 21 & & & \\
\hline \multicolumn{2}{c}{ Mean } & $\begin{array}{c}\text { Stat } \\
\text { Deviation } \\
\end{array}$ & Variance \\
& Statistic & Statistic & Statistic & Statistic \\
\hline Score & 76,0071 & 0,69012 & 3,15254 & 10,002 \\
Valid N & & & & \\
\hline
\end{tabular}

From the results of the statistical test in Table 2, it is described that the mean is 76.00 with a standard deviation of 3.16 which is in accordance with the assessment target. The survey results show an average result of $78 \%$ in the good category. The results of the questionnaire showed 89 results in the satisfactory category. From the results of student responses obtained an average of $76 \%$.

Moodle is one of LMS type that is most often used in the learning process because it considered capable of supporting the achievement of learning success. The advantages that can be obtained by using Moodle e-Learning include time and cost efficiency, easy of access and features, flexibility of study schedules, increasing independence of students, increasing student motivation, easy of providing assessments, and accommodating many media. This convenience and advantage is in line with the advantages of using LMS in learning. (Palandi et al., 2017); (Hakim, 2013).

Therefore, many campuses try to apply e-learning in the learning process.
One of them is Tanjungpura University which is the location of research by taking linear program courses as the material to be studied using the Moodle e-learning. In line with the blended learning model, universities develop elearning Moodle as the medium. By using an internet connection, the benefits of e-learning with Moodle as a learning medium can be used as a trigger to attract students' interest in the learning process. The Moodle application is functionally known as the Course Management System or Learning Management System (LMS). Moodle is short for Modular Object Oriented Dynamic Learning Environment (Azis, 2015); (Muhammad, 2017).

The elements contained in the elearning system include questions, community, online instructors, opportunities to work together, and multimedia. The characteristics of elearning in the learning process are utilizing electronic technology services, taking advantage of computer advantages, using independent teaching materials stored on computers, utilizing learning schedules, curricula, results of learning progress and matters related to educational administration can be seen at any time on computers, and materials designed and prepared by professional materials builders. (Raharja et al., 2011); (Irawan \& Surjono, 2018).

Some of Moodle view consist of teaching and learning proccess until evaluation and also the opening part can be seen in Figure 1 until 3. All figures present every important part of learning by using Blended Learning proccess. Learning proccess by using Blended Learning runs smoothly and goes well. 
DOI: https://doi.org/10.24127/ajpm.v10i2.3571

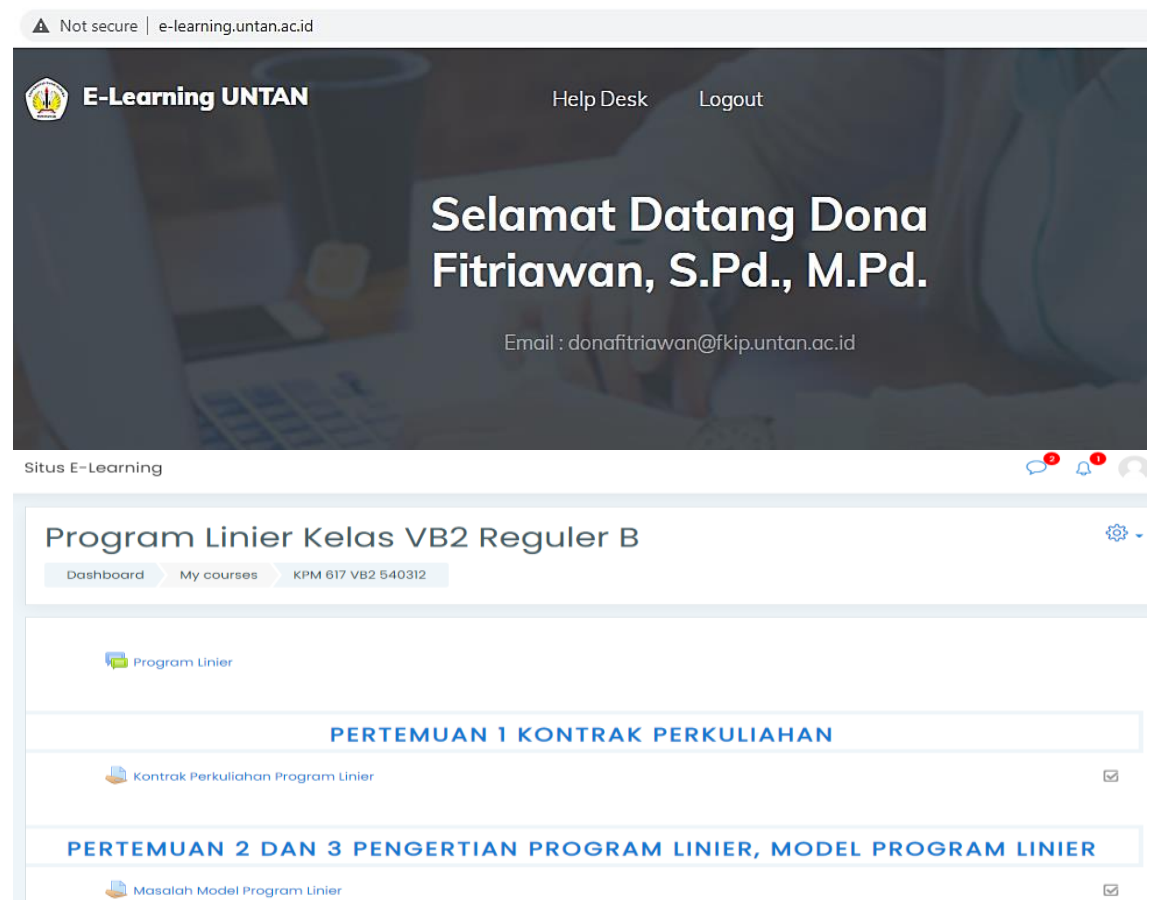

Figure 1. Blended learning based on e learning moodle in the lecture process Grading summary

\begin{tabular}{|l|l|}
\hline Hidden from students & No \\
\hline Participants & 21 \\
\hline Submitted & 20 \\
\hline Needs grading & 0 \\
\hline Due date & Tuesday, 20 October 2020, 12:00 AM \\
\hline Time remaining & Assignment is due \\
\hline Late submissions & Only allowed for participants who have been granted an extension \\
\hline
\end{tabular}

Figure 2.The process of assigning tasks in moodle e-learning

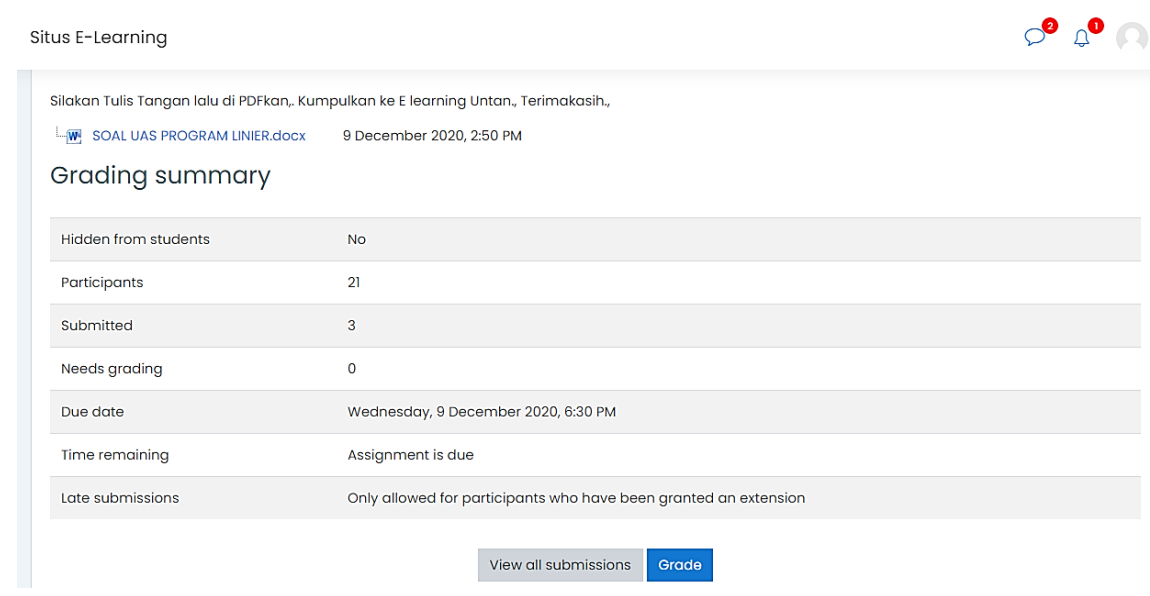

Figure 3. Process and assessment of 21 students' exam using moodle e-learning 
Discussion of the implementation results with the application of e-learning that has been carried out, obtained data from the results of a questionnaire about student attitudes towards linear program courses used blended learning model based on e-learning moodle obtained questionnaire data about student attitudes with satisfactory criteria. While student activities were obtained through surveys and response data to the learning process obtained through questionnaires to determine the practicality of the media. The research data on the response of students' attitudes to the blended learning model based on e-learning moodle showed that the average student response rate was $76.00 \%$.

The research data on student activity in using the blended learning model based on e-learning Moodle shows that the activity most accessed by students is downloading teaching materials, namely 15 students, uploading assignments of 21 students and taking quizzes of 20 students and filled out a questionnaire of 20 students. This means that from a maximum of 21 students, almost all of them have been actively involved in learning.

All lecturer activities use elearning moodle, namely face-to-face using the zoom meeting in e-learning, presence in the application, the lecture process uses the application, collection of assignments in the application, even MID and UAS have been formatted in the application. By implementing a blended learning model based on elearning moodle, there was an increase in learning achievement from the initial average of 70 to 76 and a positive response of $76 \%$.

From the results of previous studies, obtained 1) The results of Aditia Rachman et al's research by applying the blended learning model in three stages all have increased with student responses reaching 78\% (Rachman et al., 2019) and 2) the results of Deni Darmawan et al's research by applying Moodle and Facebook e-learning obtained expert validation of $93.33 \%$, the percentage of products was $90.42 \%$, and there was a significant increase when applied to ICT subjects (Darmawan \& Bariyah, 2014). This indicates that the Moodlebased blended learning model is very suitable for use in learning in higher education.

\section{CONCLUSION AND SUGGESTION}

From the results of the research and discussion, it is concluded that: 1) the blended learning model based on elearning Moodle has been successfully implemented into linear learning program courses, 2) From the results of tests, questionnaires, surveys and interviews with e-based blended learning model students -learning moodle has increased their achievement and enthusiasm for learning.

The suggestion in this research is that lecturers and students and institutions support each other in increasing understanding of ICT continuously towards the Industrial Revolution Era 4.0.

\section{REFERENCES}

Abdullah, W. (2018). Model Blended Learning dalam Meningkatkan Efektifitas Pembelajaran. Fikrotuna, 7(1), 855-866. https://doi.org/10.32806/jf.v7i1.316 9

Amin, A. K. (2017). Kajian Konseptual Model Pembelajaran Blended Learning berbasis Web untuk Meningkatkan Hasil Belajar dan Motivasi Belajar. Jurnal Pendidikan Edutama, 4(2), 51-64. 
Azis, A. A. (2015). Pengembangan Media E-Learning Berbasis LMS Moodle pada Matakuliah Anatomi Fisiologi Manusia. Jurnal Pendidikan Biologi, $\quad 7(1), \quad$ 1-8. http://journal2.um.ac.id/index.php/j $\mathrm{pb} /$ article/view/712

Hakim, A. R. (2013). Pengembangan ELearning Berbasis Moodle sebagai Media Pengelolaan Pembelajaran. Persepsi Masyarakat Terhadap Perawatan Ortodontik Yang Dilakukan Oleh Pihak Non Profesional, 53(9), 1689-1699.

Hidayat, M. T., Junaidi, T., \& Yakob, M. (2020). Pengembangan Model Pembelajaran Blended Learning dalam Meningkatkan Pemahaman Siswa Terhadap Tradisi Lisan Aceh. 25(3), 401-410.

Idris, H. (2018). Pembelajaran Model Blended Learning. Jurnal Ilmiah Iqra', 5(1), 61-73. https://doi.org/10.30984/jii.v5i1.56 2

Irawan, R., \& Surjono, herman dwi. (2018). Pengembangan E-Learning Berbasis Moodle dalam Peningkatan Pemahaman Lagu pada Pembelajaran Bahasa Inggris. 5(1), 1-11.

Jihad, A., \& Haris, A. (2013). Evaluasi Pembelajaran. Yogyakarta: Multi Pressindo.

Manggabarani, A. F., Sugiarti, \& Masri, M. (2016). Pengaruh Model Pembelajaran Blended Learning Terhadap Motivasi dan Hasil Belajar Siswa Kelas X SMA Negeri 1 Pitumpanua Kab.Wajo (Studi Pada Materi Pokok Sistem Periodik Unsur). Jurnal Chemica, 17(2), 8393.

Muhammad, T. (2017). Perancangan Learning Management System Menggunakan Konsep Computer Supported Collaborative Learning Abstraksi This time many Universities have implemented elearning to support learning activities . However AMIK Hass Bandung The Campus where Researchers c. Jurnal Produktif, 1, 35-63.

Palandi, J. F., Aminah, S., \& Pudyastuti, Z. E. (2017). Pengembangan Aplikasi Web E-Learning Untuk Pendidikan Anti Korupsi Menggunakan Moodle. INOVTEK Polbeng - Seri Informatika, 2(2), 173.

https://doi.org/10.35314/isi.v2i2.20 4

Rachman, A., Sukrawan, Y., \& Rohendi, D. (2019). Penerapan Model Blended Learning Dalam Peningkatan Hasil Belajar Menggambar Objek 2 dDmensi. Journal of Mechanical Engineering Education, 6(2), 145-152.

Raharja, S., Prasojo, L. D., \& Nugroho, A. A. (2011). Model Pembelajaran Berbasis Learning Manajement System. 41, 55-70.

Rizal, S., \& Walidain, B. (2019). Pembuatan Media Pembelajaran ELearning Berbasis Moodle Pada Matakuliah Pengantar Aplikasi Komputer Universitas Serambi Mekkah. JURNAL ILMIAH DIDAKTIKA: Media Ilmiah Pendidikan Dan Pengajaran, 19(2), 178. https://doi.org/10.22373/jid.v19i2.5 032

Sari, M. (2019). Analisis Model-model BlendedLearning di Lembaga Pendidikan. NATURAL SCIENCE: Jurnal Pendidikan IPA Dan Pendidikan IPA, 5(2), 835-847.

Sugiyono. (2017). Metode Penelitian Pendekatan Kuantitatif, Kualitatif, $R \& D$. Bandung: Alfabeta.

Wardani, D. N., Toenlioe, A. J. E., \& Wedi, A. (2018). Daya Tarik Pembelajaran Di Era 21 Dengan Blended Learning. Jurnal Kajian Teknologi Pendidikan (JKTP), 1(1), 13-18. 